\title{
AIR QUALITY MODELLING IN AL-MANSOURYIA
}

\section{AREA KUWAIT.}

\author{
Alhajri, F. S. ${ }^{(1)}$; Abo El-Nasr, M. M. ${ }^{(2)}$; Abdel-Halim, H. E. ${ }^{(2)}$; \\ Al Hajeri, N. S. ${ }^{(3)}$ and Al Fadhli, F. M. ${ }^{(4)}$
}

1) Vocational Training Institute, the Public Authority for Applied Education and Training, Kuwait. 2) Department of Mechanical Power Engineering, Faculty of Engineering, Ain Shams University 3) Department of Environmental Technology and Management, College of Life Sciences, Kuwait University, Kuwait. 4) Department of Chemical Engineering, Faculty of Engineering and Petroleum, Kuwait University, Kuwait.

\begin{abstract}
The temporal and spatial air quality was investigated and analyzed in AlMansouryia area in state of Kuwait over a period of 8 years (2004-2012) by using an air quality model to compare the changes in the levels of atmospheric pollutants and updating the database of air quality in Kuwait. Many of pollutants are emitted in air due to the combustion of fuel.

This study presents detailed analysis of air quality in Al-Mansouryia residential area, where the concentration of $\mathrm{SO} 2$ was decreased with time due to the EPA regulations, but the highest concentration was in 2005 year from North West in summer (July) and autumn (September) because of two warehouses fire in Shuwaikh industrial area. Also, concentration of NO2 is decreasing in Al-Mansouryia with the time due to the EPA regulations.

Ozone $(\mathrm{O} 3)$ concentration is wobbles between increase and decrease, but in 2006 year it was highest in North West. The NOx concentration was decreased with time, but in the 2005 and 2006 is highest, as well as gives maximum concentration is 1934 PPB. NOx and O3 depend on each other, in Kuwait when NOx increases O3 decreases when VOC is low. The CO concentration in almost all of study period was low except in summer 2006 was the highest level because a container of chemicals was on fire in the Shuwaikh port, which led to increase of $\mathrm{CO}$ emissions towards AlMansouryia from North direction. The PM10 concentration from 2008-2012 was swinging between increasing and decreasing.
\end{abstract}


Finally, the analysis data demonstrate that Al-Mansouryia is attainment area from (SO2, O3, CO), and non-attainment area from (NOx) based on national ambient air quality standards for residential areas.

Key word: modeling, air quality, atmospheric pollutants, Kuwait

\section{INTRODUCTION}

The industrial revolution has played a dominant role in changing earth's ecology. This dramatic change has negatively affected the environment, specifically natural resources, public health and sanitation. Poor air quality is one of the impacts that the industrial revolution had on the ecosystem, and it could lead to global warming and climate change (WHO 2003, Sherbinin 2007).

Air quality is a great concern to all people, as it is healthy to breathe fresh air. Air pollution is considered the most dangerous outcome of the industrial revolution because of the emissions of primary pollutants such as sulfur dioxide (SO2), carbon dioxide (CO2), carbon monoxide $(\mathrm{CO})$, nitrogen oxides (NOx) and volatile organic compounds (VOCs). In addition, the primary pollutants can react in the atmosphere to form secondary atmospheric pollutants such as ozone (O3) and particulate matter (PM10) (Daly and Zannetti. 2007).

Al-Salem et al. (2009) assessed air quality data from Kuwait to evaluate the exceedances of air pollution levels compared to allowable limits set by KEPA. The data were collected showed high concentrations of O3 in AlMansouryia area. The study suggested that the Al- Mansouryia area should be considered NOx sensitive. Also, the results showed high level of hydrogen 
sulfide was attributed to the sewage line maintenance work that was conducted during the period of the study.

These atmospheric pollutants are emitted from two source categories. The first category is anthropogenic sources and the second category is biogenic sources. Anthropogenic sources are manmade sources including electric power systems (e.g., power plants), petroleum refineries and transportation fleets (off-road and on-road vehicles). Biogenic sources are natural sources of pollution, like forest fires, volcanic eruptions and sand storms (Zemánková 2010). However, the number of atmospheric pollutants released from natural sources is relatively small compared to the huge amount released from anthropogenic sources.

Regardless of whether these pollutants come from manmade or natural sources, they have been linked to multiple adverse effects on human health and the environment. For example, NO2 can irritate the lungs and lower resistance to respiratory infections like influenza (U.S. Environmental Protection Agency [EPA], 2013). Particulate matter can deeply penetrate human lungs and reach the lower regions of the respiratory tract. Consequently, it affects breathing and causes damage to lung tissue. Also, it may cause cancer and premature death (U.S. EPA, 2013). Emissions of SO2 can form acid rain and cause damage to plants and animals. Moreover, breathing $\mathrm{CO}$ leads to death because it enters the blood stream and reacts with hemoglobin in the blood, which prevents the delivery of oxygen to the body's organs and tissues (U.S. EPA, 2013). 
Despite significant improvements in air quality due to environmental legislations and programs, emissions of air pollutants continue to negatively impact the ecosystem. Controlling air emissions and improving ambient air quality will continue to be a challenge.

During the last decades, Kuwait has gone through rapid urbanization and industrial development, which have resulted in the construction of many power and desalination plants. Also, Kuwait has many large petroleum refineries, petrochemical plants and food and cement industries. This intense increase in industrial activity could potentially create different sources of air pollution (Al-Mutairi, 2017). Therefore, studying Kuwait's air quality is very important.

There are six power plants in Kuwait that are used to simultaneously generate electricity and produce fresh water by consuming hydrocarbon energy with varied sulfur content $(\mathrm{S} \%)$. Those power plants use four types of fuel to generate electricity: heavy fuel oil (HFO), crude oil (CO), natural gas (NG) and gas oil (GO). These fuels are provided by the Kuwait Oil Company (KOC), where all of them are hydrocarbon products. The emissions caused by burning hydrocarbon products are the main sources of pollutants and generate a great number of them. These pollutants are emitted due to the combustion of fuel in boilers and include SO2, CO2, CO, NOx, PM10 and VOCs. There are many of industrial areas in Kuwait in different locations (figure 1). 


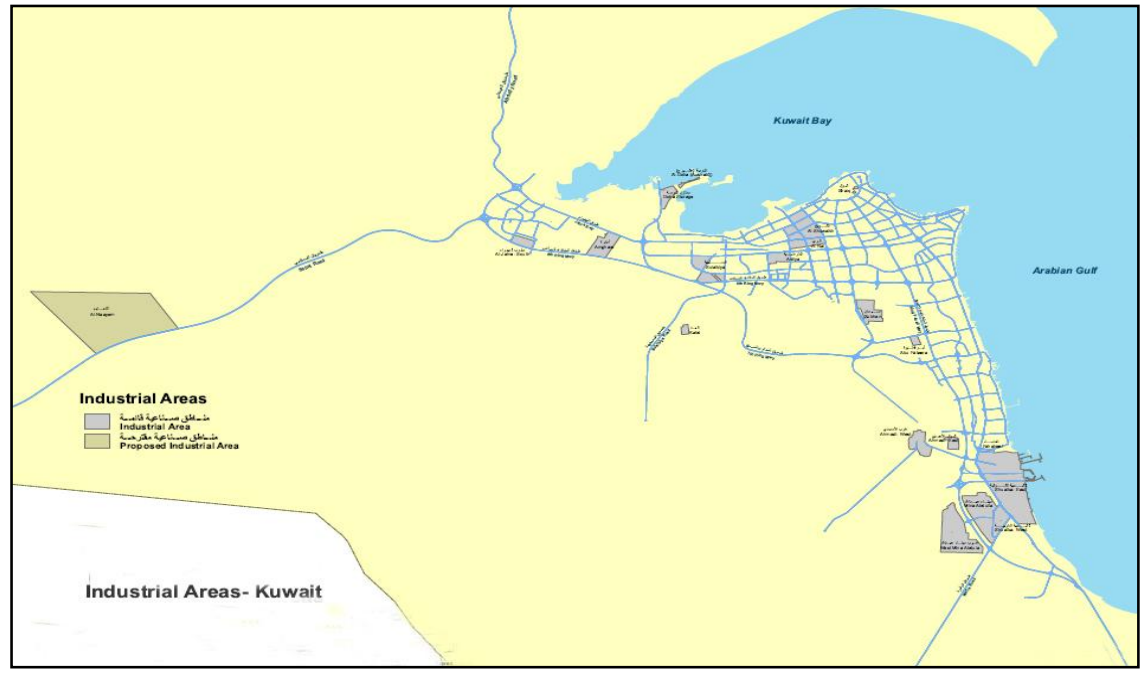

Figure(1): The distribution of industrial areas in Kuwait.

The release of air pollutants is a direct result of the process of refining oil. Every day, refineries emit about 100 chemicals, including lead and PM10, which affect human health. They also release gases like SO2, nitrogen oxides NOx, $\mathrm{CO} 2, \mathrm{CO}$, methane, hydrogen fluoride, chlorine, and other poisonous gases. There are three petroleum refineries in Kuwait. From north to south, they are Ahmadi, Shuaiba and Abdulla Port. All of these petroleum refineries are located in the Al-Ahmadi governorate.

Oil and gas fields greatly contribute to air pollution through drilling activities and gas burning in the gathering centers. There are 14 oil and gas fields in Kuwait, four of them are sea fields and the rest of which are land fields. Marlowe et al. (1995) conducted a study on the environmental impacts of petrochemical system. It was found that Oil refineries pollute our air, water and land. Oil refineries cause smog and air pollution. Almost all refineries in 
every country currently pollute at unacceptable, unhealthy levels. The main sources of $\mathrm{CO} 2$ emission in a refinery are including Power Plants (Producing Steam and /or Electricity), Process Furnaces and Boilers, Flares, Process Vent Emissions.

The process of burning gas at the gathering centers results in gaseous emissions from pollutants such as $\mathrm{CO}, \mathrm{CO} 2, \mathrm{NOx}, \mathrm{SO} 2, \mathrm{CH} 4$ and nonmethane hydrocarbons (NM-HC) (Najjar 2011). There are no monitoring stations in any of the oil fields and gathering centers, which make the situation worse. Thus, it is difficult to collect information regarding the emissions from gathering centers.

The Kuwait Air Quality Index (KAQI) is calculated for five major air pollutants regulated by the List of Executive Orders (210/2001) of the National Environment Law No 21 for which the Environment Public Authority of Kuwait has established national air ambient quality standards to protect public health: Sulphur Dioxide (SO2), Nitrogen Dioxide (NO2), Ground-Level Ozone (O3), Carbon Monoxide (CO), and Particulate Matter (PM10). When the KAQI value of any of the above pollutants goes above 100 , then the air quality is considered to be unhealthy- at first for certain sensitive groups of people, then for everyone as KAQI values increase.

\section{RESEARCH OBJECTIVES}

The goal of this thesis is to cover several objectives that are relevant to the air quality in Al-Mansouryia area status of Kuwait. This study is divided into two main sections. 
1. Investigate temporal and spatial air quality trends in the state of Kuwait over a period of 12 years (2004-2015) by using an air quality model to compare the changes in the levels of atmospheric pollutants, such as ( $\mathrm{SO}$, NO, NO2, NOX, CO2, CO, O3, and PM10).

2. Identify predominate sources of those pollutants in order to help the policymakers to control the emissions from those pollutants.

\section{MATERIAL AND METHODS}

1 Spatial and temporal Air Quality Trend in Kuwait: The objective of this work is to examine the historical trend of atmospheric pollutants in the AlMansouryia area, Kuwait. There are 14 air quality monitoring stations in Kuwait that measure and record concentration levels every five minutes. The measured pollutants are including; $\mathrm{CO}, \mathrm{CO} 2, \mathrm{SO} 2, \mathrm{NOx}, \mathrm{M}-\mathrm{HC}, \mathrm{NM}-$ $\mathrm{HC}$ and $\mathrm{O} 3$. The raw data and the metrological parameters are then sent to KEPA. The average hourly data of the pollutants to be examined will be obtained from KEPA and fed to the Open Air package. The Open Air package includes open source tools for analyzing air pollution data. The model will be run to determine the daily, monthly and annual concentrations of the pollutants of monitoring station. The levels of pollutants will be analyzed to study the changes (increased, decreased or stable) in the atmospheric concentrations of these pollutants.

2 Analyzing Kuwait Air Quality Using Open Air Software: Open Air is the professional services automation (PSA) solution from resource management and project management. Open-air is an $\mathrm{R}$ package which is 
developed primarily for analyzing data to measure air pollution, the program have a set of tools available for the analysis and understanding of air pollution data in an open source environment or closed. The available data is due to availability of monitoring stations by the Environment Public Authority (EPA). Open Air has different approaches to analyze data in terms of functions that are used to specify the purpose of the program which is study and discover new pollutants sources and know how to control it.

3 Study sites: Analysis of air quality carried out in Al-Mansouryia area in Kuwait.

3.1 Al-Mansouryia area: It is one of the residential areas, which is located in Kuwait City, consists of two blocks, and it is one of the small residential areas, approximately $125.53 \mathrm{Km}^{2}$ and the population is proximity equal to 8,352. Four major roads surrounded Al-Mansouryia area; the Morocco highway, the first Ring road, second ring road, and Cairo Street (figure 2). Pollutant sources in Al-Mansouryia area was magnified in figure 3.

4 Input data: The data of air monitoring station from 2004 to 2012, data is hourly including wind speed, wind direction, and pollutants which are NO2, SO2, NO, NOx, CO, PM10, and O3. From 2004 to 2011 years we need to change the concentration units of $\mathrm{NO}, \mathrm{NO} 2, \mathrm{NOx}, \mathrm{O} 3$, and $\mathrm{SO} 2$ from part per million (ppm) to part per billion (ppb). EPA calculated NOx as the summation of concentrations of both $\mathrm{NO}$ and $\mathrm{NO} 2$. 


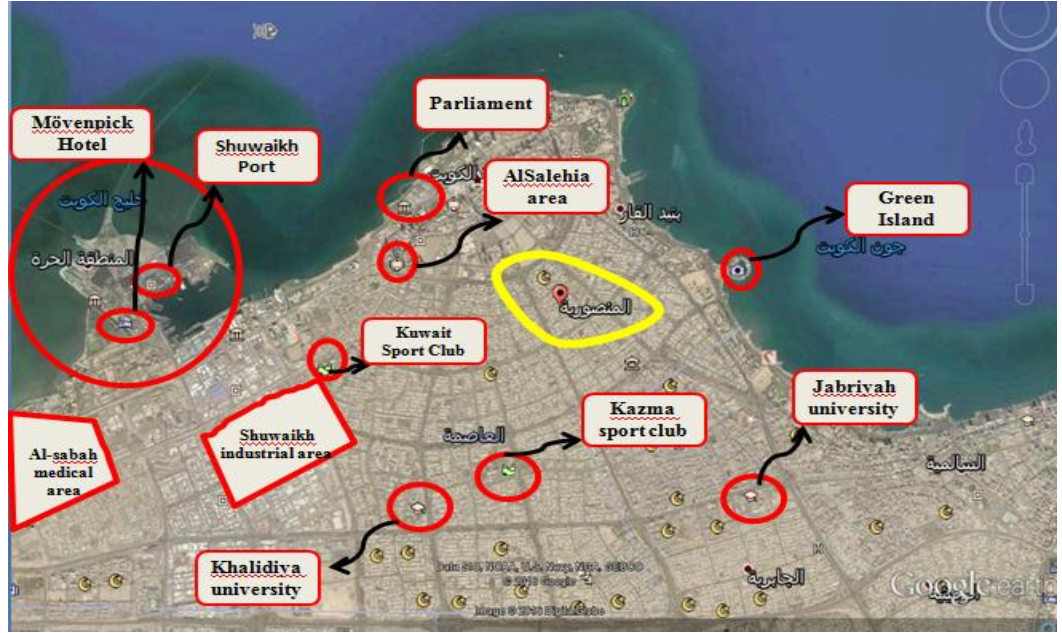

Figure(2): The location of Al-Mansouryia area.

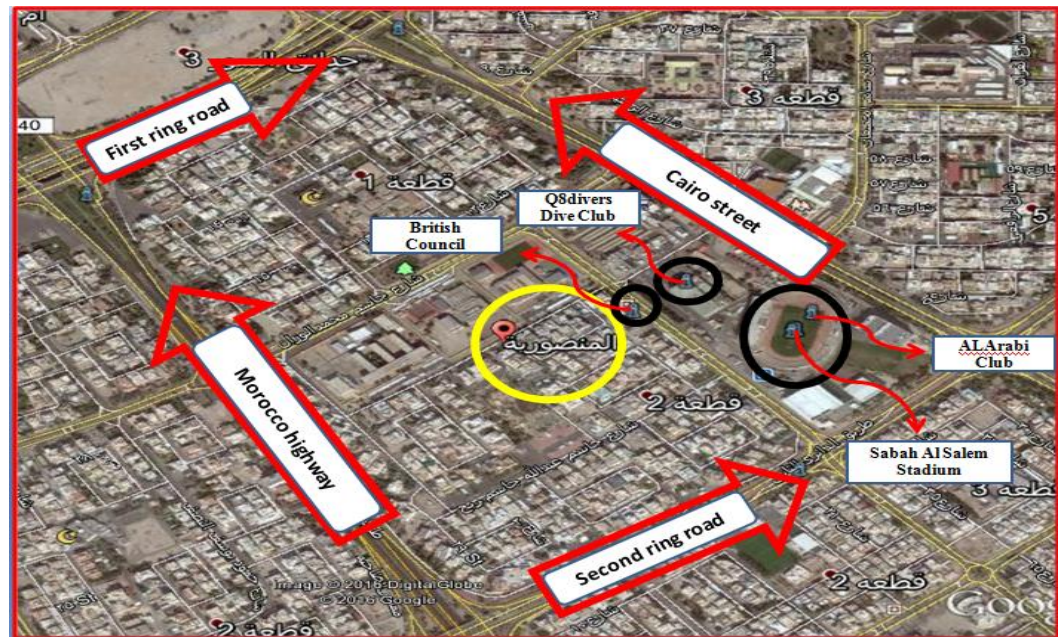

Figure(3): Pollution sources

The unit of CO used in this study was (ppm), the unit of PM10 is microgram per cubic meter $(\mu \mathrm{g} / \mathrm{m} 3)$ and the unit of wind speed is $(\mathrm{m} / \mathrm{s})$ and the parameters of wind direction (degree). 


\subsection{Mobile stations}

- AC32M. Nitrogen oxides analyzer (NO, NOx, NO2)

- O342M. Ozone analyzer

- HC51M. Hydrocarbon analyzer

- AF22M. Sulfur dioxide analyzer

\subsection{Open Air functions}

- Import function: This function uses to import data and help to format dates of data to be use in open air software. By typing my data import and then choose the file to open in the dialog box, the open air will assume the date field in format (dd/mm/yyyy HH:MM). Import function is very flexible because can take many format of different date.

- Wind Rose function and Pollution Rose: Wind Rose is a way to summarize data by knowing the effect of wind speed and direction every year, month, season, or days. Where is in the open air classification of the wind speed in different paddles and direction by 30 or 45 degrees. This function shows the relationship between the concentration of pollutant and wind speed and direction.

- Time Variation: In time variation function clarifies how pollutants vary with time, that thing can show very important information considering pollutant sources. This function clarifies four plots: day of the week variation, mean hour of day variation and a combined hour of day-day of week plot and a monthly plot. The plots are $95 \%$ confidence interval in the mean. 


\section{RESULTS AND DISCUSSION}

Data of Environment Public Authority (EPA) will analyze the air pollutants for Al-Mansouryia areas in Kuwait by using open-air software. Furthermore, it will explain the ratios for each pollutant, SO2, NO, NO2, NOx, O3, CO, and PM10 and it will identify the reasons of patterns, principles, relationships in observed data and sources of pollutants.

It is mainly residential area surrounded by main roads, Four major roads surrounded Al-Mansouryia area; the Morocco highway, the first Ring road, second ring road, and Cairo Street. Mostly the pollution in this area is representing motor road pollutants (Al-Bassam and Khan 2004). The following part illustrate each pollutant individually that may affect air quality in the Al-Mansouryia area.

Sulfur dioxide (SO2): Data presented in table 1 shows an hourly mean concentration, maximum concentration, and standard deviation of SO2 from 2004-2012. The maximum hourly concentration was recorded in 2005 with large difference between the actual and the average value in 2005. So, the value of standard deviation was highest in 2004 and 2005. It is clear that concentration of SO2 decreasing with time due to the EPA regulations, which forces industrial area emissions, and the diesel uses in the transportation system in Kuwait contain low-sulfur in the last years. The highest concentration was in 2005 approximately 34.5 PPB (figure 4).

The summary of plot functions in open-air software was given comprehensive view of data for SO2 from 2004-2012. It is clear that the concentration decreases with time, but in 2005 is higher than the remaining 
years, as well gives maximum concentration is 557 PPB (figure 5). In addition, the mean value during the study period is 11.6 PPB. Moreover, the percentage of missing data equal $6.1 \%$, which is less than $25 \%$ so data Valid for study.

Table(1): Sulfur dioxide (SO2) classification for Al-Mansouryia area

\begin{tabular}{|c|c|c|c|}
\hline Year & $\begin{array}{c}\text { Mean } \\
\text { Concentration }\end{array}$ & $\begin{array}{c}\text { Maximum } \\
\text { concentration }\end{array}$ & $\begin{array}{c}\text { Standard } \\
\text { deviation }\end{array}$ \\
\hline \hline 2004 & 24.4 & 551 & 22.2 \\
\hline 2005 & 34.5 & 557 & 22.2 \\
\hline 2006 & 19.4 & 521 & 19.2 \\
\hline 2007 & 7.8 & 280 & 10.1 \\
\hline 2008 & 5.2 & 95 & 5.6 \\
\hline 2009 & 4.1 & 106 & 4.8 \\
\hline 2010 & 4.1 & 69 & 3.4 \\
\hline 2011 & 3.4 & 37 & 2.6 \\
\hline 2012 & 4.1 & 82.82 & 2.8 \\
\hline
\end{tabular}

The location, wind direction, and wind speed was studied in AlMansouryia to determine the concentration for SO2. Wind-rose function help to determine the wind direction of each year and wind speed to know how wind influence. The wind direction was North West in all years which mean all SO2 sources in the North West. 


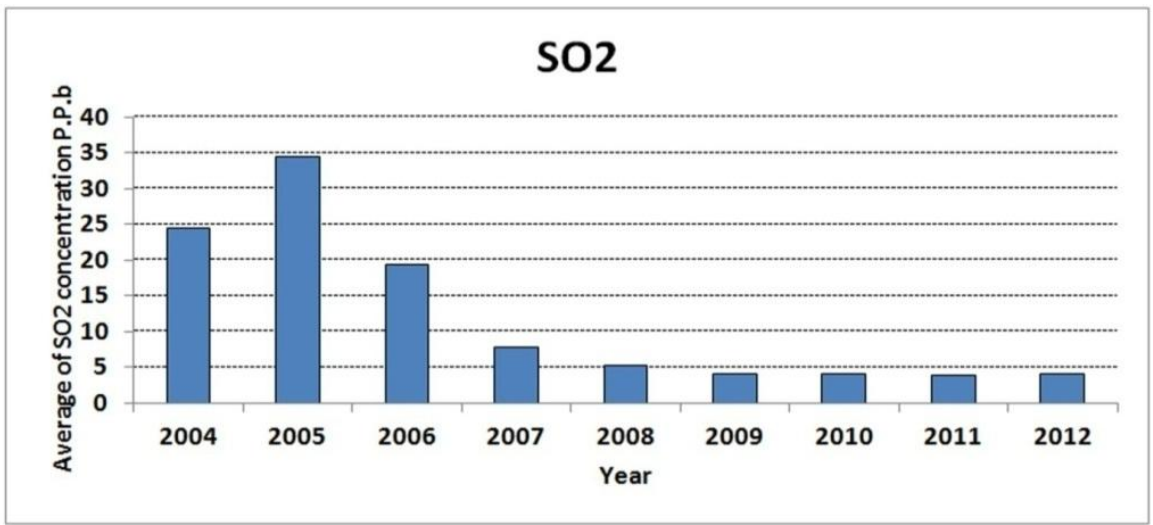

Figure(4): Mean concentration of SO2 for Al-Mansouryia area

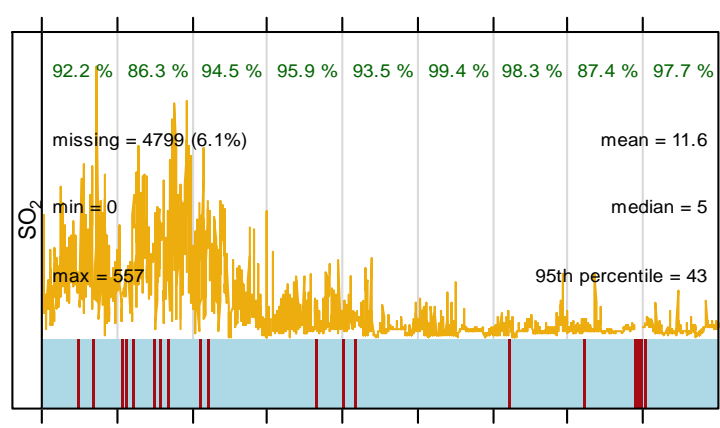

200420052006200720082009201020112012

date

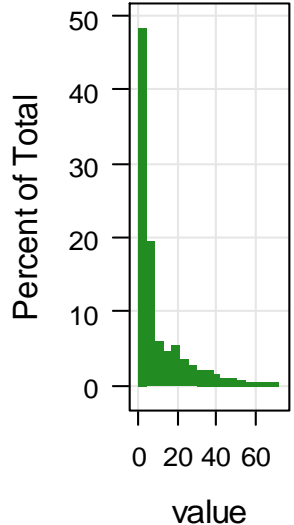

value

Figure(5): Summary plot of SO2 for Al-Mansouryia area 


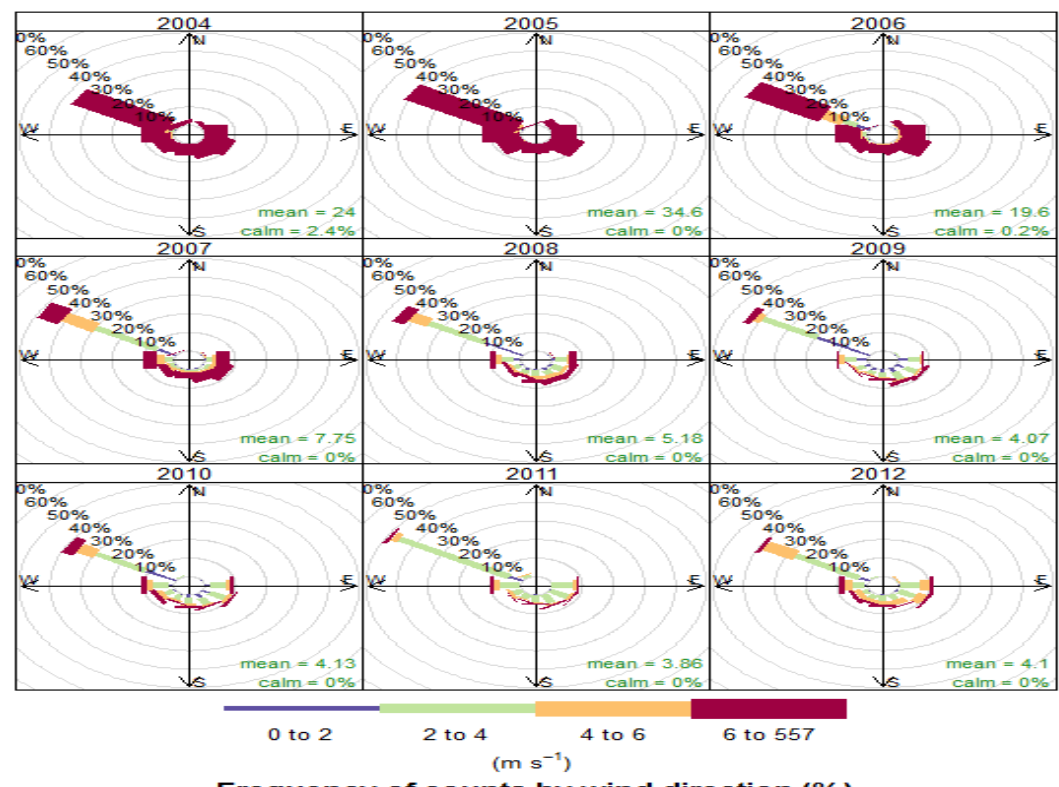

Figure(6): Wind rose of SO2 for Al-Mansouryia

Figure 6 shows the wind direction is North West in all years which mean all SO2 sources in the North West. In addition, 2004 and 2005 the highest frequency of SO2 concentration is when the wind is North West.

Nitrogen dioxide (NO2): Data presented in table 2 and illustrated in figure 7 show the concentration of NO2 was decreasing with time due to the EPA regulations. The highest concentration was in 2005 approximately 72 PPB and in 2006 was 64.6 in Kuwait due to many reasons the main reason is the crowded in the main ring roads. 
The number of exceeds based on the standards of EPA set for allow the able concentration of NO2 within the residential area. The highest exceeds in 2005 is 1826 due to the heavy fuel oil burned in power plants contains a high percentage of pollutants (figure 8).

Table(2): Nitrogen dioxide (NO2) classification for Al-Mansouryia

\begin{tabular}{|c|c|c|c|}
\hline Year & $\begin{array}{c}\text { Mean } \\
\text { concentration }\end{array}$ & $\begin{array}{c}\text { Maximum } \\
\text { concentration }\end{array}$ & $\begin{array}{c}\text { Standard } \\
\text { deviation }\end{array}$ \\
\hline 2004 & 45.9 & 300 & 39.1 \\
\hline 2005 & 72.3 & 669 & 63.6 \\
\hline 2006 & 64.6 & 992 & 103.3 \\
\hline 2007 & 24.8 & 384 & 19 \\
\hline 2008 & 28 & 195 & 21.5 \\
\hline 2009 & 31.2 & 192 & 25.7 \\
\hline 2010 & 42.2 & 389 & 34.8 \\
\hline 2011 & 34 & 509 & 28.5 \\
\hline 2012 & 44.9 & 247.4 & 32.8 \\
\hline
\end{tabular}

The Concentrations of NO2 was varying by wind speed and wind direction. As shown in 2005 year the highest concentration is in the north and North West because of two main highways. In 2004 year, high concentration was in west and slightly toward south west from Shuwaikh industrial area and Sabah hospital. 
J. Environ. Sci.

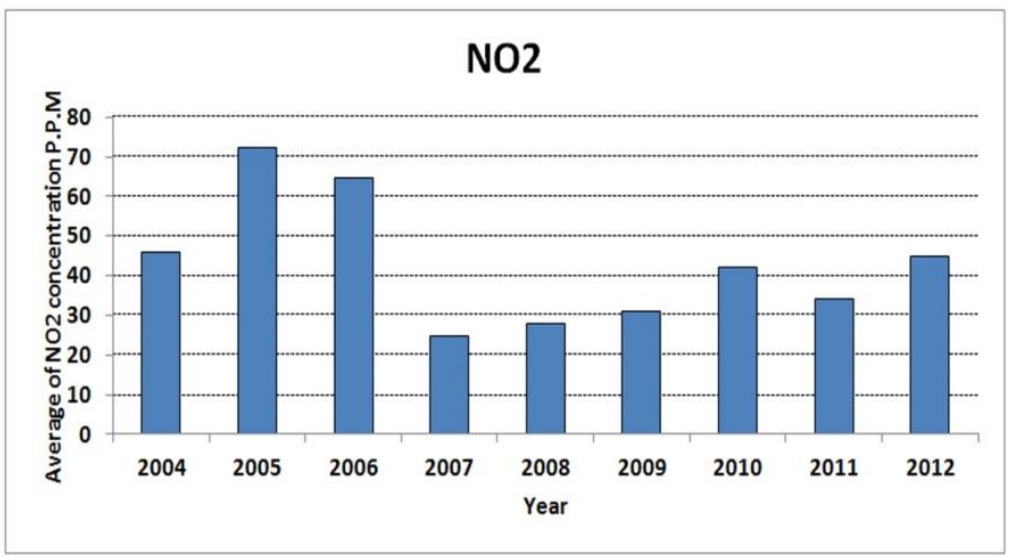

Figure(7): Mean concentration of NO2 for Al-Mansouryia area

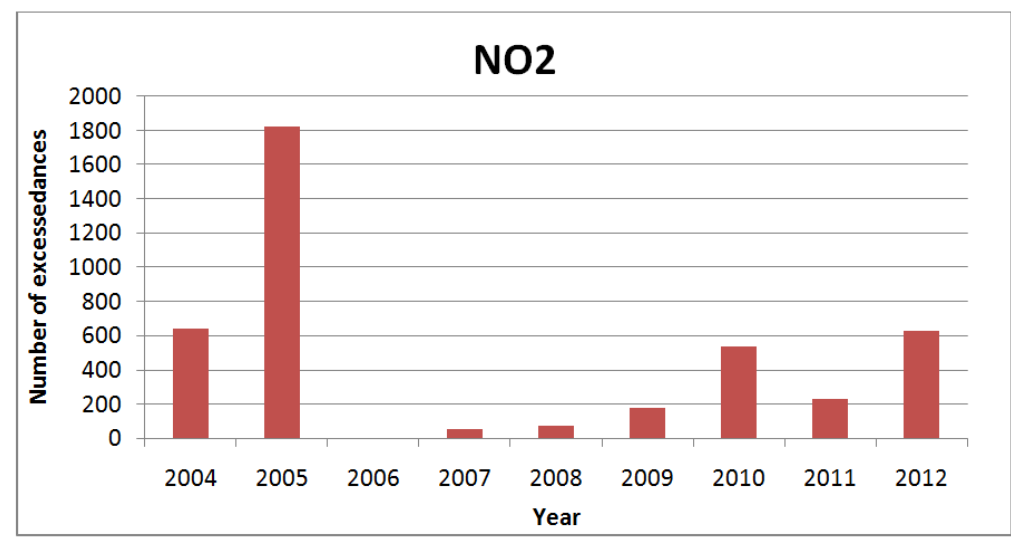

Figure(8): Nitrogen dioxide (NO2) exceeds for Al-Mansouryia area

Nitrogen oxides (NOx): The table 3 shows an hourly mean concentration, maximum concentration, and Standard deviation of NOx from 2004-2012. The maximum hourly concentration was in 2005, but large difference between the actual and the average value was in 2006. The concentration of NOx decreased with time, but in the 2005 and 2006 years was highest, as well as gives maximum concentration (1934 PPB). In addition, the mean value 90 
during the study period is $79.7 \mathrm{PPB}$ with percentage of missing data equal $13.6 \%$.

The polar plot figure 9 shows the highest concentration in 2005 is in the north due to the two main highways: first ring road and Arabian Gulf Street that is always crowded. In 2005 ministry of transportation, co-operate with EPA starting to clean up the Coastline of Kuwait University beach along Alhura zone with Kuwait Bay from contaminated soil is a result of the existence of shipwrecks, which led to contaminated Kuwait Bay and AlGhazali coastline and spread of pollutants in the air.

Table(3): Nitrogen oxides (NOx) classification for Al-Mansouryia

\begin{tabular}{|c|c|c|c|}
\hline Year & $\begin{array}{c}\text { Mean } \\
\text { concentration }\end{array}$ & $\begin{array}{c}\text { Maximum } \\
\text { concentration }\end{array}$ & $\begin{array}{c}\text { Standard } \\
\text { deviation }\end{array}$ \\
\hline \hline 2004 & 112 & 1053 & 106.9 \\
\hline 2005 & 169 & 1147 & 206.9 \\
\hline 2006 & 138.1 & 1934 & 225.7 \\
\hline 2007 & 48.8 & 899 & 62.3 \\
\hline 2008 & 49 & 932 & 61.1 \\
\hline 2009 & 50.4 & 1016 & 66.5 \\
\hline 2010 & 68.6 & 1330 & 87.3 \\
\hline 2011 & 60.5 & 1085 & 72.8 \\
\hline 2012 & 72.8 & 721.6 & 80.3 \\
\hline
\end{tabular}


J. Environ. Sci.

Institute of Environmental Studies and Research - Ain Shams University

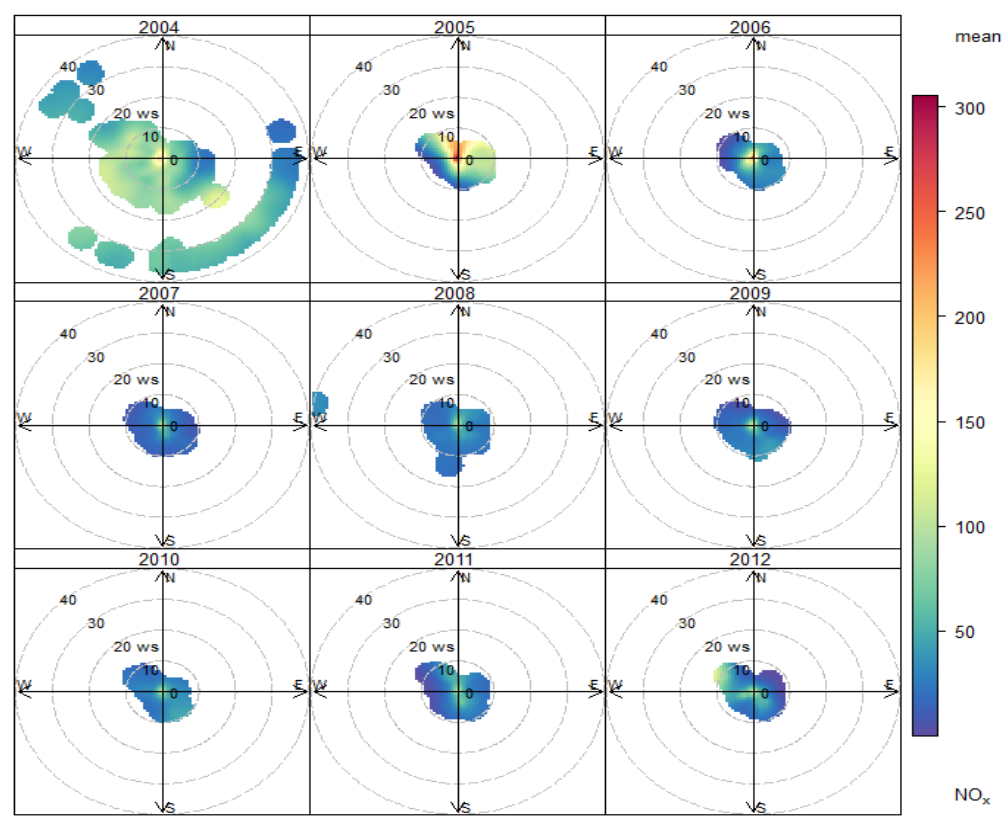

Figure(9): Polar plot of NOx for Al-Mansouryia

In 2004, 2005, and 2006 the most affected area in the north because of contaminated Kuwait bay from Sabah Hospital waste and industrial areas, as well as sewage from Mishref sewage treatment plant. The last years of study show a decrease in the concentration of NOx because Government's cares about clean up Kuwait bay area and Imposes punishments on that pollute this area.

- Ozone (03): Data presented in table 4 shows hourly mean concentration, maximum concentration with standard deviation of O3 from 2004-2012. The maximum hourly concentration was in 2007, but large difference between the actual and the average value in 2007, so that the standard deviation is highest. The concentration of $\mathrm{O} 3$ was varying between 
increasing and decreasing. The concentration of $\mathrm{O} 3$ is not always high because $\mathrm{O} 3$ depends on the concentration of volatile organic compound. As shown the highest concentration approximately 25.7 PPB in 2006. The number of $\mathrm{O} 3$ exceeds was equal zero in last three year (figure 10).

So, Al-Mansouryia is attainment area of $\mathrm{O} 3$, but the highest $\mathrm{O} 3$ exceeds was in 2009 due to crowded roads which led to increase emissions of cars. The polar plot shows the concentration of $\mathrm{O} 3$ in the daylight was higher than night time specially surrounding Al-Mansouryia. The In the time variation used for 2006 was highest concentration of O3.

Table(4): Ozone (O3) classification for Al-Mansouryia area

\begin{tabular}{|c|c|c|c|}
\hline Year & $\begin{array}{c}\text { Mean } \\
\text { concentration }\end{array}$ & $\begin{array}{c}\text { Maximum } \\
\text { concentration }\end{array}$ & $\begin{array}{c}\text { Standard } \\
\text { deviation }\end{array}$ \\
\hline 2004 & 14.2 & 93 & 8.8 \\
\hline 2005 & 20.8 & 191 & 12.8 \\
\hline 2006 & 25.7 & 238 & 17 \\
\hline 2007 & 24.4 & 450 & 19.4 \\
\hline 2008 & 21.6 & 208 & 15.1 \\
\hline 2009 & 21.4 & 212 & 15.2 \\
\hline 2010 & 17.6 & 72 & 10 \\
\hline 2011 & 17.2 & 60 & 9.1 \\
\hline 2012 & 20.1 & 79.92 & 10.3 \\
\hline
\end{tabular}

In 2006, concentration of O3 was increased sharply in June where the weather is hot and the power plants emissions increase due to increase in the consumption of electricity. 
J. Environ. Sci.

Institute of Environmental Studies and Research - Ain Shams University

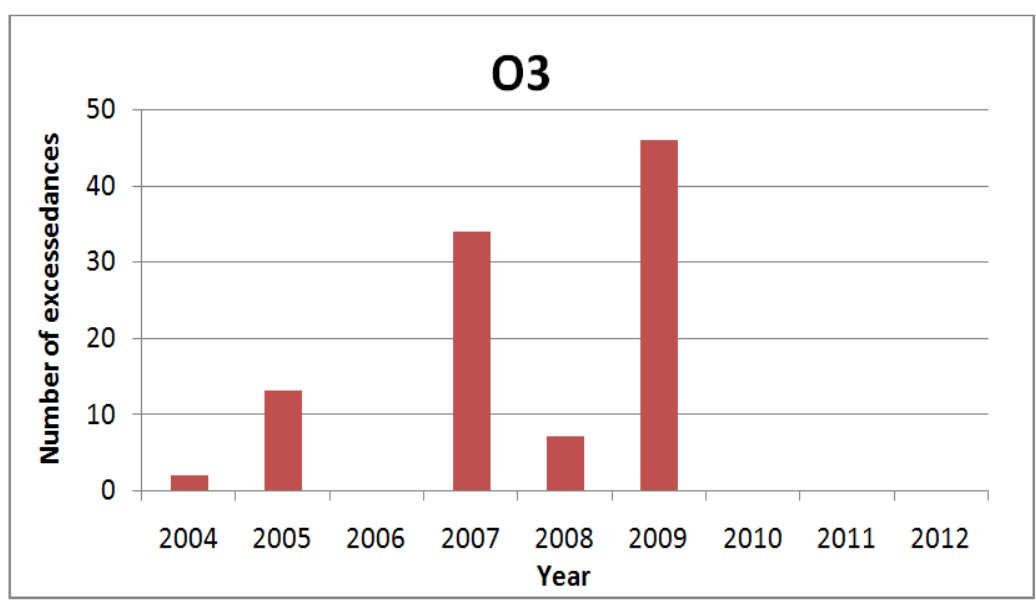

Figure(10): Ozone exceeds for Al-Mansouryia area

- Carbon Monoxide (CO): Data presented in table 5 shows the concentration with SD (CO) from 2004-2012, where the maximum hourly concentration was in 2006 and large difference between the actual and the average value was in 2006. The concentration of CO swings through study period (figure 11), where concentration of $\mathrm{CO}$ is not high because most of the cars are new and under maintenance services annually. The highest concentration was recorded in 2004 and 2006 approximately 1 PPM in Kuwait. The number of exceeds from 2004-2012 based on the standards of EPA set for the allowable concentration of $\mathrm{CO}$ within the residential area.

Where, the number of exceeds was equal zero in all study period that means Al-Mansouryia has air quality as good as the national ambient air quality standards of $\mathrm{CO}$, so that Al-Mansouryia is attainment area of $\mathrm{CO}$. 
Table(5): Carbon Monoxide (CO) classification for Al-Mansouryia area

\begin{tabular}{|c|c|c|c|}
\hline Year & $\begin{array}{c}\text { Mean } \\
\text { concentration }\end{array}$ & $\begin{array}{c}\text { Maximum } \\
\text { concentration }\end{array}$ & Standard deviation \\
\hline \hline 2004 & 1.1 & 8.06 & 0.41 \\
\hline 2005 & 0.4 & 6.58 & 0.53 \\
\hline 2006 & 1 & 12 & 1.53 \\
\hline 2007 & 0.9 & 7.75 & 0.47 \\
\hline 2008 & 0.6 & 7.88 & 0.66 \\
\hline 2009 & 0.6 & 7.85 & 0.62 \\
\hline 2010 & 0.7 & 8.63 & 0.68 \\
\hline 2011 & 0.8 & 8.6 & 0.73 \\
\hline 2012 & 0.9 & 8.24 & 0.71 \\
\hline
\end{tabular}

The concentration of $\mathrm{CO}$ in the summer was high in the north and slightly North West. While in the winter, the concentration was high from North West and south which increase concentration-surrounding AlMansouryia where emissions from cars increase in cold weather due to increase need for fuel to run and the process of raise $\mathrm{CO}$ in the atmosphere are slow. Therefore, the CO concentration increases near earth's surface. 
J. Environ. Sci.

Institute of Environmental Studies and Research - Ain Shams University

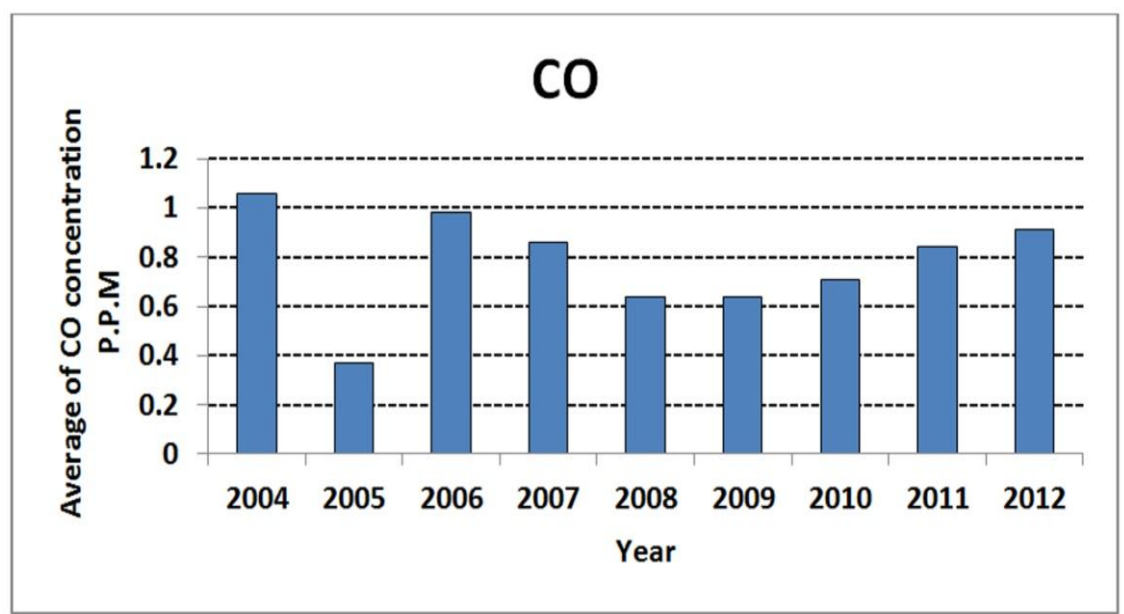

Figure(11): Mean concentration of CO for Mansouryia area

- Particulate matter (PM10): The maximum hourly concentration of PM10 was in 2008, but large difference between the actual and the average value was in 2012 (Figure 12). The concentration of PM10 swings between increasing and decreasing through study period. The highest concentration was in 2012 is approximately $296.5 \mu \mathrm{g} / \mathrm{m}^{3}$. In 2008 year, the highest concentration of PM10 was in the North East especially in autumn season.

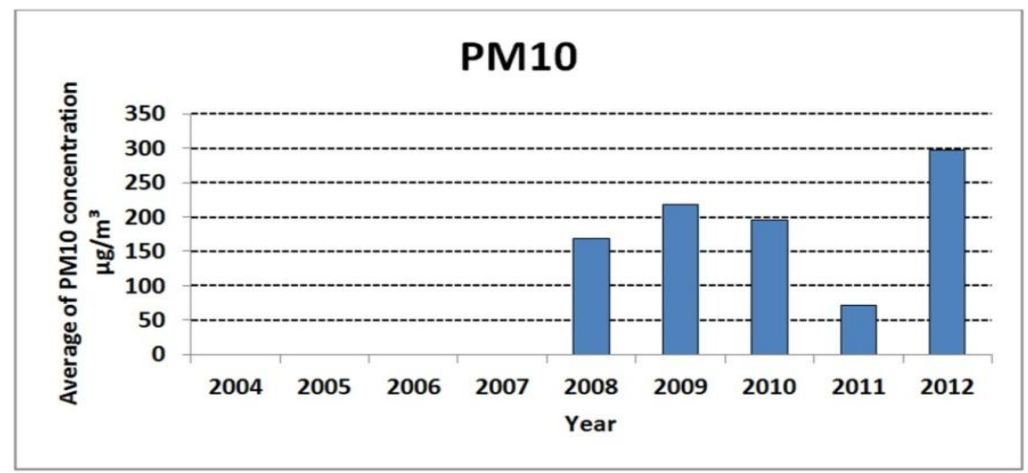

Figure(12): Mean concentration of PM10 for Al-Mansouryia 
In the year 2009, the main roads near and inside Al-Mansouryia from west maybe are crowded so that the reaction of NOx and SO2 form PM10.

However, in 2012 the concentration of PM10 was high in the autumn and summer from North West because of movement of PM10 from desert areas.

At the end of work, we summarize the analysis data as shown in the figure 13, where Al-Mansouryia was attainment area from $(\mathrm{SO} 2, \mathrm{O} 3, \mathrm{CO})$, and non-attainment area from (NOx) based on KEPA standards for residential areas.

\section{CONCLUSION}

Al-Mansouryia is attainment area from ( $\mathrm{SO} 2, \mathrm{O} 3, \mathrm{CO})$, and the nonattainment area from (NOx) based on national ambient air quality standards for residential areas.

\section{REFERENCES}

Al-Bassam E. and Khan A. (2004). Air pollution and road traffic in Kuwait .Urban Transport X, 741-750.

Alex de Sherbinin1, David Carr, Susan Cassels, and Leiwen Jiang (2007). Population and Environment Annu Rev Environ Resour. 32: 345373. doi:10.1146/annurev.energy.32.041306.100243.

Al-Salem, S., Al-Fadhlee, A., and khan, A., (2009). Ambient Air Quality Assessment of Al-Mansoriah residential Area the State of Kuwait", The Journal of Engineering Research. 6(2):52-63.

Al-Salem, S.M. (2015). Investigating the Global and Specific Carbon Dioxide (CO2) Emissions from the Petroleum Downstream Industry of Kuwait. 
Asma'a Al-Mutairi, Andrew Smallbone, S.M. Al-Salem, Anthony Paul Roskilly (2017). The first carbon atlas of the state of Kuwait. Energy 133 - $317 \mathrm{e} 326$

Daly, A. and P. Zannetti. (2007). An Introduction to Air Pollution Definitions, Classifications, and History. The Arab School for Science and Technology (ASST)

Edward S. Rubin, Chao Chen, and Anand B. Rao, (2007). Cost and performance of fossil fuel power plants with $\mathrm{CO} 2$ capture and storage.

Intergovernmental Panel on Climate Change, IPCC (2005).

Kateřina Zemánková (2010). Study of links between biogenic VOC emissions and concentration of tropospheric ozone. Ph.D. thesis, Faculty of Mathematics and Physics Department of Meteorology and Environment Protection Charles University, Prague

Kuwait Air Quality Index (KAQI) (2011/2012). http://www.beatona.net/CMS/index.php?option=com_content\&vi ew $=$ article $\& i d=61 \&$ lang $=$ en $\&$ Itemid $=84$

Marlowe I.T, Lindsell P.H.R., Byfield S, and Jones C. (1995). The categorization or volatile organic compounds. Part II, AEA Technology confidential report, May 1995. Subsequently published by the department of the environment as report DoE/HMIP/RR/95/009.

Roland R. Draxler, Jeffery T. McQueen, Barbara J.B. Stunder (1994). An Evaluation of Air Pollutant Exposures due to the 1991 Kuwait Oil Fires using a Lagrangian Model. Atmospheric Environment, 28, (13): 2197-2210,

Sawyer R.F and Harley R.A. (2000). Mobile sources critical review. 1998 NARSTO assessment, Atmospheric Environment, 34(12-14):161181.

United States Environmental protection Agency (U.S.EPA) 2013. Health Effects of Air pollution. Air Program. (accessed June 2014). 
U.S. Environmental Protection Agency [EPA], 2013. Improved Information Could Better Enable EPA to Manage Electronic Waste and Enforce Regulations Report No. 13-P-0298.

WHO (2003). Climate change and human health, risks and responses. 333pp.

Yassin, M. and AL-Awadhi, M., (2011). Impact of sulfur Dioxide Emissions of power stations on Ambient Air Quality", Environmental Engineering Science, 28(7): $469-475$.

Yousef S. H. Najjar (2011). Gaseous Pollutants Formation and Their Harmful Effects on Health and Environment. Ashdin Publishing Innovative Energy Policies Vol. 1, Article ID E101203, 8 pages

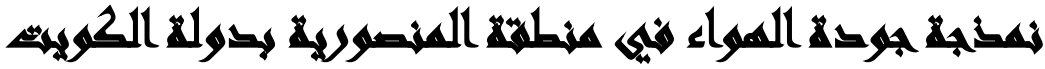

\section{[६]}

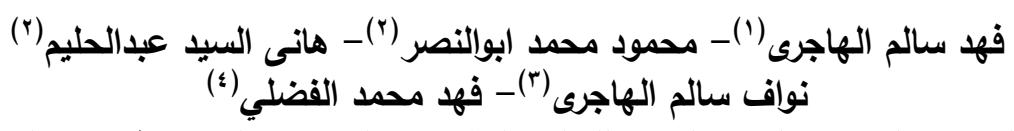

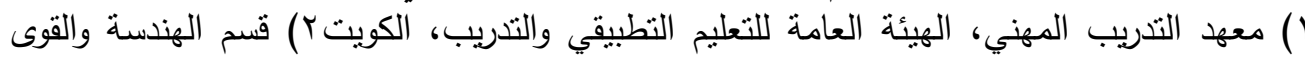

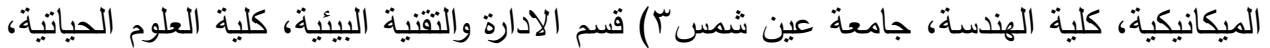

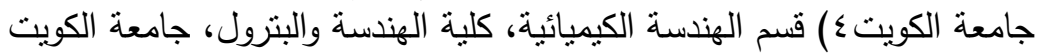

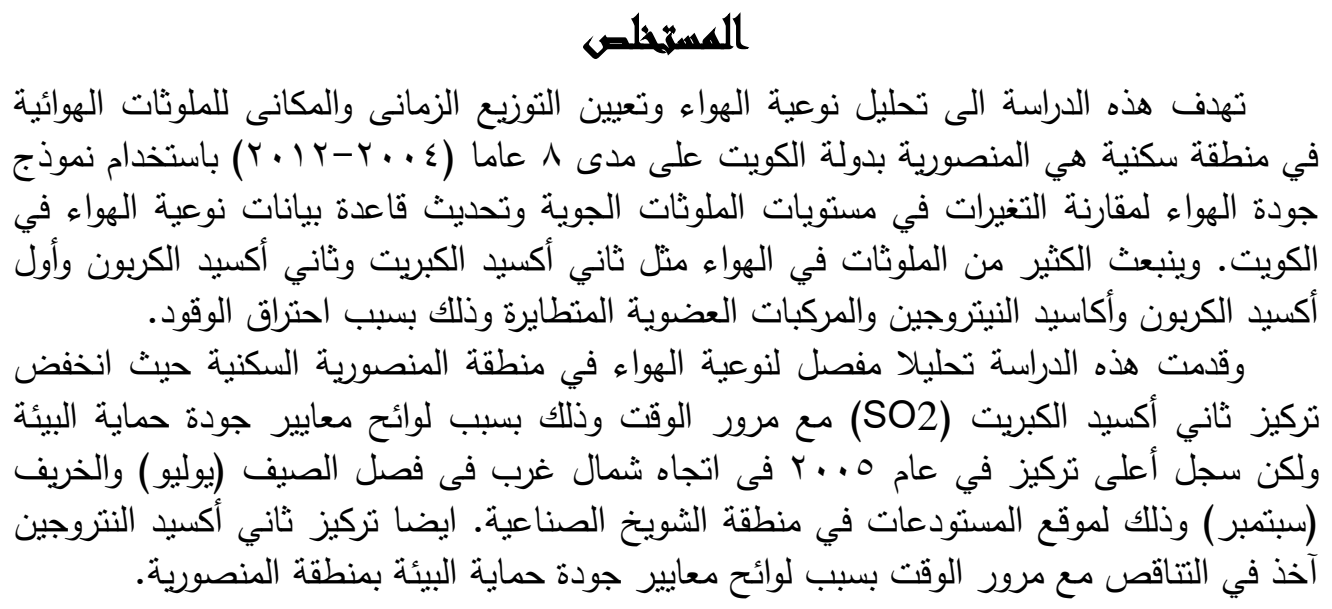


الأوزون (O3) ثانى ملوثات الهواء ينشئ في وجود ضوء الثئ الثمس أثناء تفاعل أكاسيد النيتروجين

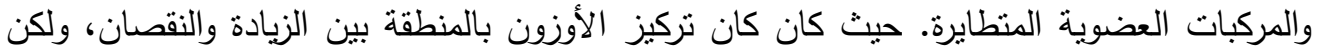

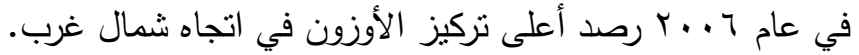

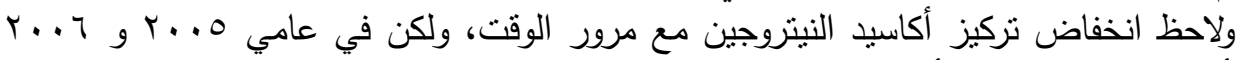

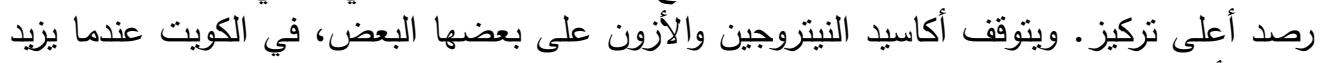

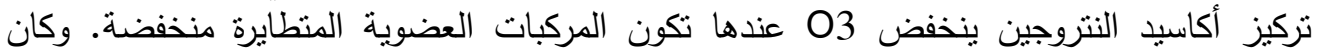

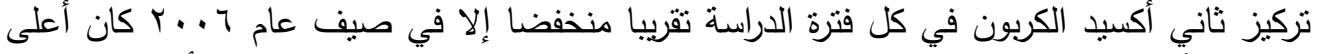

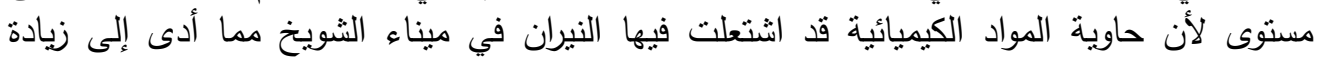
انبعاثات ثاني أكسيد الكربون باتجاه المنصورية من اتجاه الثمال. أما تركيز بين زيادة وتتاقص خلال فترة الدراسة.

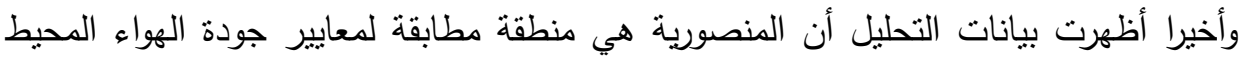

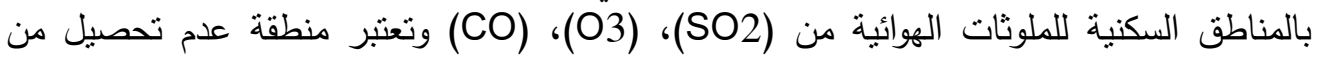
(NOx) 